\title{
New Asymmetries in the New Authoritarianism: Research in Egypt in the Age of Post-Revolution LUCIE RYZOVA
}

Department of History, University of Birmingham, Birmingham, UK; e-mail: 1.ryzova@bham.ac.uk

doi:10.1017/S002074381700037X

Egypt was at the center of a wave of uprisings and revolutions that swept the region between 2011 and 2013, the common denominator of which was demands for a radical democratic alternative to authoritarian regimes variously formulated around social justice and political rights. While the Middle East was a major theater of these events, with Tunisia, Egypt, Lybia, Syria, Bahrain, and Yemen sharing the headlines, the processes that informed these uprisings were also deeply global. The year 2011 was a revolutionary year, maybe the last in history, when actors differently positioned in the neoliberal social landscape mobilized in different ways, from the Occupy Movement to the London riots. The demise, or better, defeat, of these movements has reverberated profoundly around the globe, highlighting the postdemocratic nature of governance in contemporary states. ${ }^{1}$ One of the effects of the rise of new authoritarianism across Europe and the United States is a palpable transformation in the asymmetry between outside observer and the local observed. Researchers now face a reshaping, in some ways a leveling, of differences between "us" and "them" and the distinct temporality used to underpin this asymmetry. Nothing could illustrate this better than the fact that as I write, Egypt's president 'Abd al-Fattah al-Sisi is enjoying a warm welcome in the White House. The narrative is no longer framed through the worn-out trope of an Arab leader aspiring to modernize his country through pledging allegiance to the leader of the Free World in exchange for aid and armaments; now the man in the White House implicitly pledges to learn from the Arab dictator. Egypt is the pioneer; the United States is the relative latecomer to the Age of New Authoritarianism.

Have these processes affected the ways we conduct research in Egypt? Certainly. The cataclysmic event for European and American researchers was the case of Giulio Regeni, brutally tortured to death in January 2016. As a number of observers and commentators pointed out (many of them of Giulio's age and, like him, postgraduate researchers working in Egypt), this event upset the long-established privilege enjoyed by foreign researchers of exemption from the kind of physical danger that Egyptians are exposed to. ${ }^{2}$ For decades the primary dangers threatening foreign scholars included the denial of a visa or research permit, or, at worst, expulsion. Giulio's death had the effect of leveling the playing field between foreign researcher and an Egyptian informant, turning the former from a "bystander" or "witness" to a direct participant in enduring the consequences of social enquiry. It had for effect a kind of dark justice exemplified in the slogan "Regeni is one of us, he died like us," that appeared on banners and graffiti to commemorate his death. ${ }^{3}$ With the real horror and symbolic effect of Regeni's death acknowledged, it ought to be stressed that this appears to have been a one-off event. ${ }^{4}$ Egyptians remain in incomparably greater danger than foreigners. Aside from the greater risk of torture and death that Egyptians endure, Egyptian researchers have of course also born the bulk of less corporal dangers, 
with scores of them having been denied either entry or travel permits. Nor should the words "foreigner" and "Egyptian" be taken at face value. While these categories remain deeply potent in many social situations, there are also many different shades of foreigner and what is meant here is the white middle-class researcher with a western passport.

In Egypt suspicion towards "foreign researchers" has expectedly been mobilized throughout the counter-revolutionary rollback over the past four years. A selective "unmasking of foreign agendas" currently forms one of the key tenets of the al-Sisi regime's legitimacy and has a palpable presence in both state-controlled and independent media. There have been cases of journalists and researchers arrested from coffee shops for talking politics as the current political climate encourages a "police thy neighbor" behavior. ${ }^{5}$ But this suspicion has a long history in Egypt and cannot be considered a radically new phenomenon. ${ }^{6}$ There is no question that some research topics are effectively off limits to researchers committed to working with human sources, notably research on the Muslim Brotherhood, Human Rights, and/or nongovernmental organizations, and most topics too directly or too obviously related to the recent revolutionary process. But there is also a difference between experienced researchers and novices, namely postgraduate students. Rules of discretion apply, including a sense of what one can do and what not. Such instinct and discretion is best acquired with time; time itself in this sense can be considered a training method, which allows the thickening of experience. The game is not necessarily qualitatively different for historians hoping to access Egyptian National Archives, but in the ebb and flow of archival access the first few postrevolutionary years have certainly been an "ebb period." After a period of marked improvement during the revolutionary years of 2011-13, the permit situation is at its worst in living memory, or certainly within the living memory of relatively young researchers, who report much longer waiting times and a sense of precarious uncertainty hanging over their permit applications. $^{7}$

When it comes to historical research, older trends have intensified. Egyptian archives have been notoriously difficult institutions for decades, seeing their mission as controlling and preventing access to historical records rather than facilitating research. In a situation where the failure (whether real or perceived) of the postindependence state to care for historical artefacts has been widely acknowledged, a new trend of creating private archives has sprung up around the region over the past decade coupled with a newfound nostalgia for colonial heritage as a Golden Age of prosperity and once-held modernity. The radical democratic possibilities that reverberated through 2011-13 also entailed hope for a new kind of openness of research and of history. ${ }^{8}$ The defeat of these visions brought about not only the continued (and increased) policing of records housed in national depositories, but also the increased privatization of those not housed there. The commercialization of historical artefacts dating to the past roughly one hundred years (and therefore exempt from Egypt's national heritage laws) has intensified; private, personal, and family collections originating from estate sales are leaving the country practically on an everyday basis, most of them heading towards individual and institutional collections in the Gulf countries. Historians of modern Egypt have more recently started mining private and family archives, and a number of excellent works have recently been undertaken based on them. However, the accelerating privatization of historical sources opens serious questions about their accessibility in the future. 
In Egypt, the revolutionary process between 2011 and 2013 continues to cast a long shadow over encounters between local and foreign subjects and the expectations and relationships born out of them. This applies to interdisciplinary research on contemporary topics. Revolution brought in the "parachute" researcher, and even more so, the journalist, who came with money to be showered on local assistants and fixers. ${ }^{9}$ It also created "stars" on the local level, people who became the favorite subjects of interviews; some were heroes, others were opportunists, and this line sometimes may have been blurred. While this "revolution bubble" is long gone, it continues to shape newly forged personal relationships on the ground. The effects of these relations are diverse and yet palpable. Some citizens of Middle Eastern revolutionary societies who had previously benefited from this bubble pined for the "glory days" of international attention; others, by contrast, consider it important to facilitate the work of researchers who still come even when the cause appears to have been lost. Foreigners interested in Egypt now, after all the dashed hopes and the quick and easy fame that could once be gained from research, journalism, or documentary making has gone, may enjoy a kind of aura of genuineness. Yet their Egyptian interlocutors may remain deeply wary of the "activist-talking-to-journalist" dynamic, often for very good reasons.

But crucially, this sense of precariousness is not unique to the region, and should emphatically not be read as a discouragement. The Middle East is not necessarily more volatile and unpredictable than other places on the planet. Here, the silver lining of the defeat of democratic uprisings in the region rests in the ways the global rollback of authoritarianism has shattered western countries' long-standing claim on normalcy (or positive exceptionalism) and, specifically, the illusion of there being "normal" and safe conditions for carrying out research. The "researcher" is increasingly becoming the villain in the United Kingdom, the United States, and other parts of the formerly democratic west. In the United States scholars and students (even undergraduates) face increasing vigilantism from self-appointed political commissars aiming to stifle speech that they claim promotes "hatred of the USA, Israel and Jews on college campuses." 10 The United Kingdom pressures academics and universities to conduct "counterterrorism" surveillance on students and to censor speech that the government defines as "opposition to fundamental British values."11 A right-wing Hungarian government has voted for a de facto closure of a university. ${ }^{12}$ Everywhere business models of university practice erode the conduct of social scientific and humanistic research. The reshaping and, from some perspectives, even the leveling of hierarchies between "us" and "them," is thus less the product of Giulio Regeni's brutal death as it is the effect of broad anti-intellectualist trends in western societies. Whatever standards of academic freedom may have once been thought to pertain to universities in Europe and the United States can no longer be considered secure. The specter of criminalizing academic research in places like London, Paris, or Chicago no longer seems far-fetched.

\section{NOTES}

${ }^{1}$ See, for instance, Colin Crouch, Post-Democracy (Cambridge: Polity, 2004); Achille Mmembe, "The Age of Humanism Is Ending," Mail \& Guardian, 22 December 2016, accessed 17 April 2017, https://mg.co.za/ article/2016-12-22-00-the-age-of-humanism-is-ending/; and Nafeez Mosaddeq Ahmed, "Donald Trump Is Not the Problem, He Is the Symptom," Open Democracy, 20 January 2017, accessed 17 April 2017, https:// www.opendemocracy.net/nafeez-mosaddeq-ahmed/donald-trump-is-not-problem-he-s-symptom. 
${ }^{2}$ Though it is important to stress which Egyptians. Class has always played a role in the ways Egyptians were treated by their jailors, but the revolutionary process of 2011-13 importantly reshaped these hierarchies. With the important exception of Khalid Sa id in June 2010, middle-class Egyptians were not subject to physical torture under the Mubarak regime in the same routine manner as low-income men, nor to class-based forms of police bullying. This has now changed, with young middle-class people being equally subject to physical violence and especially to forced disappearances and arbitrary detention.

${ }^{3}$ See the website Another Scratch in the Wall, accessed 20 March 2017, https://anotherscratchinthewall. com/2016/05/12/giulio-regeni-an-egyptian-like-us-interview-to-el-teneen-naguib-and-iahmed/.

${ }^{4}$ Interpretations of it range from the act of a rough agent to part of a power struggle between different security services to embarrass the presidency.

${ }^{5}$ Maha Abdelrahman, "Report Thy Neighbour: Policing Sisi’s Egypt," Open Democracy, 23 February 2015, accessed 17 April 2017, https://www.opendemocracy.net/5050/maha-abdelrahman/report-thy-neighbourpolicing-sisi\%E2\%80\%99s-egypt.

${ }^{6}$ Reem Saad, "Shame, Reputation and Egypt's Lovers: A Controversy over the Nation's Image," Visual Anthropology 10 (1998): 401-12.

${ }^{7}$ I thank Pascale Ghazaleh and an anonymous foreign researcher who did not wish to be named for sharing their experiences with me.

${ }^{8}$ See Khaled Fahmy, “The Production of Knowledge," Egypt Independent, 6 March 2012, accessed 17 April 2017, http://www.egyptindependent.com/opinion/production-knowledge; and Fahmy "The Tragedy of Books in Egypt," Ahram Online, 29 August 2012, accessed 17 April 2017, http://english.ahram. org.eg/News/51572.aspx.

${ }^{9}$ Mona Abaza, “Academic Tourist Sight-Seeing the Arab Spring," Jadaliyya, 27 September 2011, accessed 17 April 2017, http://www.jadaliyya.com/pages/index/2767/academic-tourists-sight-seeing-the-arab-spring.

${ }^{10}$ Canary Mission, accessed 5 April 2017, https://canarymission.org/.

${ }^{11} \mathrm{HM}$ Government, "Prevent Duty Guidance," accessed 5 April 2017, http://www.legislation. gov.uk/ukdsi/2015/9780111133309/pdfs/ukdsiod_9780111133309_en.pdf

${ }^{12}$ David Matthews, "Central European University in Peril as Hungary Passes Law," 4 April 2017, accessed 5 April 2017, https://www.timeshighereducation.com/news/central-european-university-peril-hungarypasses-law. 